\title{
Distribution and Heredity of Erythrocyte G6PD Activity and Electrophoretic Variants Among Different Racial Groups at São Paulo, Brazil ${ }^{\star}$
}

\author{
P. H. SALDANHA, F. G. NÓBREGA, and J. C. C. MAIA \\ From the Laboratórios de Genética e Enzimologia, Departamento de Bioquimica, Faculdade de Medicina da \\ Universidade de São Paulo, Brazil
}

In human beings the production of glucose-6phosphate dehydrogenase (G6PD) in erythrocytes is controlled by genes in the $\mathrm{X}$ chromosome (Childs et al., 1958; Kirkman and Hendrickson, 1963; Nance, 1964). At least 20 different mutants affecting the physico-chemical properties and decreasing the synthesis of the enzyme were described (Kirkman, McCurdy, and Naiman, 1964; World Health Organization, 1967). The most frequent mutants in human populations are those responsible for the normal A+ (fast) and B+ (slow) phenotypes, identified by their relative electrophoretic mobilities (Boyer, Porter, and Weibacher, 1962). The A type is found only among American Negroes while the B type is common in Mediterranean Caucasians and Americans of European origin. Enzyme-deficient subjects presenting any electrophoretic phenotypes, designated by A - (Negro) and $B$ - (Mediterranean), were described in variable fractions of those populations (Porter et al., 1963).

It was also shown that the enzymic defect of the red cells is the primary factor determining haemolytic anaemia in deficient subjects, after the ingestion of broad beans (Vicia faba) or substances containing 8-aminoquinoline, which include antimalarial drugs such as primaquine (review in Beutler, 1959). There are more G6PD-deficient people in Africa (Allison, 1960; Motulsky, Vandepitte, and Fraser, 1966; Gilles et al., 1967), the Mediterranean basin (Siniscalco et al., 1961; Allison et al., 1963; Plato, Rucknagel, and Gershowitz, 1964; Modiano et al., 1965; Ragab, El-Alfi, and Abboud, 1966; Shaker, Onsi, and Aziz, 1966), Asia (Lee et al., 1963; Flatz and Sringam, 1964), and America (Lisker, Loria, and Cordova, 1965), possibly be-

Received June 20, 1968.

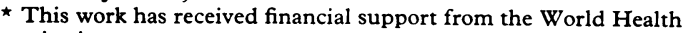
Organization. cause such people are more resistant to the Plasmodium parasite than normal persons. This hypothesis is also suggested by a positive correlation between the incidence of G6PD deficiency and sickle-cell haemoglobin in Africa (Motulsky and Kampbell-Kraut, 1961; Allison and Clyde, 1961) and/or thalassaemia in the Mediterranean region (Siniscalco et al., 1961, 1966). However, this current view has been questioned (Kruatrachue et al., 1962, 1966).

The present study was conducted in order to establish comparative patterns of G6PD activity and electrophoresis for the populations of São Paulo.

\section{Material and Methods}

The material represents two samples. Population data include healthy unrelated adults surveyed in different institutions of São Paulo. The Caucasians were predominantly drawn from among university students, and almost all of them were of Mediterranean ancestry (Italian and Portuguese). Negroes are represented by donors attending the Blood Bank of the Clinical Hospital, but no effort was made to discriminate between mixed and unmixed subjects. The third racial group is comprised of unmixed Japanese adults in co-operative institutions and also of donors at the Blood Bank. Family data were based on 18 propositi and their relatives ascertained in the Clinical Hospital, mostly because of haemolytic or undiagnosed anaemias. A few propositi included in the family data (Table I) are G6PD deficient subjects identified in the population survey.

Blood was taken in acid citrate dextrose (ACD) solution and maintained at $4^{\circ} \mathrm{C}$. for no longer than 48 hours before G6PD assay and electrophoresis. Red cells, washed 3 times (buffy coat discarded), were haemolysed with 9 volumes of distilled water and centrifuged at $5000 \mathrm{~g}$ at $4^{\circ} \mathrm{C}$. for 20 minutes to remove stroma. The supernatant was used in the spectrophotometric assay of the enzyme. For electrophoresis, washed red cells were haemolysed with one volume of gel buffer containing $1 \mathrm{mM}$ of 2-mercaptoethanol and half volume of toluene. G6PD assay 
was performed at $25^{\circ} \mathrm{C}$. (thermostatized) in a Cary 14 recording spectrophotometer by using premixed reagents from Calbiochem. The unit of activity was defined as the quantity of enzyme which produces an optical density change of 1.0 per minute at $340 \mathrm{~m} \mu$. G6PD activity was expressed as units per g. haemoglobin.

Other investigators (cf. Dern, 1966) refer to G6PD activity as $\mu \mathrm{M}$ of nicotinamide adenine dinucleotide phosphate (NADP) reduced $/ g$. Hb/hour. This estimate can be indirectly obtained by multiplying the previous unit by $29 \cdot 1$.

Horizontal starch gel electrophoresis was performed with paper inserts (Whatman $3 \mathrm{~mm}$.) at $5 \mathrm{~V} / \mathrm{cm}$. for 14 hours at $4^{\circ} \mathrm{C}$. and $p \mathrm{H} 8 \cdot 6$. Buffer was tris-borateEDTA mixture, as described by Shows, Tashian, and Brewer (1964). Starch gel was prepared according to Smithies (1959). The gel was sliced and the enzyme was located by the tetrazolium staining technique (Shows et al., 1964).

\section{Results}

\section{Population Data.}

Enzyme Rates. Table I presents range of distribution, mean, and standard error of mean corresponding to the enzyme rates of 277 individuals classified by sex and race. Normal distribution of enzyme activity is based only on the study of unrelated subjects sampled at random, while data relating to G6PD deficiency also represent individuals ascertained through propositi in the Clinical Hospital (see Fig. 3) plus 5 deficient subjects (4

TABLE I

RANGE OF DISTRIBUTION AND MEAN \pm STANDARD ERROR OF ERYTHROCYTE G6PD ACTIVITY ( $\Delta$ O.D. min. $\mathrm{g}$. Hb\%) OF 250 NORMAL SUBJECTS, 13 HETEROZYGOTES, AND 14 DEFICIENT INDIVIDUALS CLASSIFIED BY SEX AND RACE

\begin{tabular}{|c|c|c|c|c|}
\hline Race & Sex & No. & Range & Mean \pm S.E. \\
\hline & \multicolumn{3}{|c|}{ Normal Subjects } & \\
\hline Caucasian & $\begin{array}{l}\text { Male } \\
\text { Female } \\
\text { Both }\end{array}$ & $\begin{array}{r}72 \\
37 \\
109\end{array}$ & $\begin{array}{l}6 \cdot 12-14 \cdot 80 \\
6 \cdot 31-14 \cdot 00 \\
6 \cdot 12-14 \cdot 80\end{array}$ & $\begin{array}{l}9 \cdot 59 \pm 0.16 \\
9 \cdot 35 \pm 0 \cdot 26 \\
9 \cdot 51 \pm 0.14\end{array}$ \\
\hline Japanese & $\begin{array}{l}\text { Male } \\
\text { Female } \\
\text { Both }\end{array}$ & $\begin{array}{l}43 \\
41 \\
84\end{array}$ & $\begin{array}{l}7 \cdot 40-13 \cdot 88 \\
6 \cdot 73-14 \cdot 07 \\
6 \cdot 73-14 \cdot 07\end{array}$ & $\begin{array}{r}9 \cdot 96 \pm 0.24 \\
10.09 \pm 0.26 \\
10.02 \pm 0.18\end{array}$ \\
\hline Negro & $\begin{array}{l}\text { Male } \\
\text { Female } \\
\text { Both }\end{array}$ & $\begin{array}{r}49 \\
8 \\
57\end{array}$ & $\begin{array}{l}5 \cdot 30-13 \cdot 51 \\
4 \cdot 01-12 \cdot 79 \star \\
4 \cdot 01-13 \cdot 51^{\star}\end{array}$ & $\begin{array}{l}8.81 \pm 0.25 \\
8.68 \pm 1.06 \\
8.79 \pm 0.26\end{array}$ \\
\hline \multirow[b]{2}{*}{$\begin{array}{c}\text { Caucasian }+ \\
\text { Negro }\end{array}$} & \multicolumn{3}{|c|}{ Heterozygotest } & \\
\hline & $\begin{array}{r}\text { Female } \\
D e\end{array}$ & 13 & $2 \cdot 10-6 \cdot 71$ & $4 \cdot 15 \pm 0 \cdot 43$ \\
\hline $\begin{array}{c}\text { Caucasian } \\
+ \\
\text { Negro }\end{array}$ & $\begin{array}{l}\text { Male } \\
\text { Female } \\
\text { Both }\end{array}$ & $\begin{array}{l}13 \\
1 \ddagger \\
14\end{array}$ & $\frac{0 \cdot 69-2 \cdot 26}{0 \cdot 69-2 \cdot 26}$ & $\begin{array}{l}1.46 \pm 0.01 \\
1.47 \\
1.46 \pm 0.01\end{array}$ \\
\hline
\end{tabular}

* Some heterozygotes could be included.

† Including family data (see Fig. 3 ).

¥ The male parent was not tested to confirm the deficient genotype (see F. V. in Fig. 3).
Negroids and 1 Caucasian) identified during the population survey. Heterozygote levels of enzyme were studied in relatives of the propositi (see Fig. 3). Women were considered heterozygous on the basis of their deficient father or son and/or on the basis of the electrophoretic findings (see Fig. 3).

The graphical distribution of normal G6PD levels among Caucasians, Negroids, and Japanese is shown in Fig. 1. It is apparent that normal rates of G6PD activity are variable among the different racial groups (cf. Table II) but not among the sexes (see Table I). The average normal values observed among Japanese $(10 \cdot 00 \pm 0 \cdot 12)$ are significantly higher than the mean rates found among Whites $(9 \cdot 51 \pm 0 \cdot 14)$ and Negroes $(8 \cdot 79 \pm 0 \cdot 26)$. The mean difference between the Negro and Caucasian is also significant (cf. Table II).

TABLE II

ANALYSIS OF VARIANCE OF G6PD ACTIVITY AND COMPARISON OF AVERAGE ACTIVITY BETWEEN RACIAL GROUPS

\begin{tabular}{|c|c|c|c|}
\hline \multicolumn{4}{|c|}{ Analysis of Variance } \\
\hline Sources of Variation & $\begin{array}{c}\text { Sum } \\
\text { of } \\
\text { Squares }\end{array}$ & d.f. & $\begin{array}{l}\text { Mean } \\
\text { Square }\end{array}$ \\
\hline $\begin{array}{l}\text { Between groups } \\
\text { Within groups } \\
\text { Total }\end{array}$ & $\begin{array}{r}51 \cdot 4 \\
669 \cdot 1 \\
720 \cdot 5\end{array}$ & $\begin{array}{r}2 \\
247 \\
249\end{array}$ & $\left.\begin{array}{c}25 \cdot 7 \\
2 \cdot 7 \\
1 \cdot 7\end{array}\right\}_{p}<0.01$ \\
\hline
\end{tabular}

Comparison between Racial Groups

\begin{tabular}{l|c|c|c}
\hline \multicolumn{1}{c|}{ Groups } & $t$ & d.f. & \multicolumn{1}{c}{$p$} \\
\hline Caucasian $\times$ Negro & 2.5 & 164 & $=0.015$ \\
Caucasian $\times$ Japanese & 2.2 & 191 & $=0.03$ \\
Negro $\times$ Japanese & 3.8 & 139 & $=0.0002$ \\
\hline
\end{tabular}

Since enzyme levels of unrelated males exhibit clear bimodal distribution, with no overlapping, the frequency of deficient subjects can be estimated from population data. Deficient enzyme levels found among population subjects (mean $=1.32$ ) are comparable $(t=0.87)$ to the rates of the deficient propositi (mean $=1 \cdot 55$ ). Table III presents the incidence of G6PD deficiency among the three racial groups. The frequencies are significantly different and, as expected, the proportion of deficient individuals among Negroes is higher compared to that in Caucasians and Japanese (see Table III).

Electrophoretic Studies. Blood samples of subjects belonging to three racial groups were investigated by means of horizontal electrophoresis. The mobility of all haemolysates was compared to those of known controls belonging to the $A$ and $B$ types of the enzyme (Fig. 2). 
Table IV presents the population distribution of $A$ and B patterns of G6PD among 225 unrelated persons. Male Negroes display about $12 \%$ of the A band, which is absent among Caucasians and Japanese. The A variant occurred only in two heterozygous 'white' women, probably of Negro ancestry. The female sample among Negroes was too small to include structural heterozygotes with normal activity $(\mathbf{A}+/ \mathbf{B}+)$. Moreover, it is likely

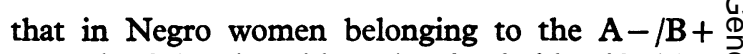
type, the A band could not be clearly identified be- $\stackrel{\Phi}{+}$ cause of the decreased activity of the enzyme (cf. $\vec{F}$ Boyer et al., 1962).

Family Data. Genetic analysis of G6PD activity and electrophoretic variants was based on 18 families, most of whom were ascertained through $\varrho$ propositi attending the Clinical Hospital of the $\&$

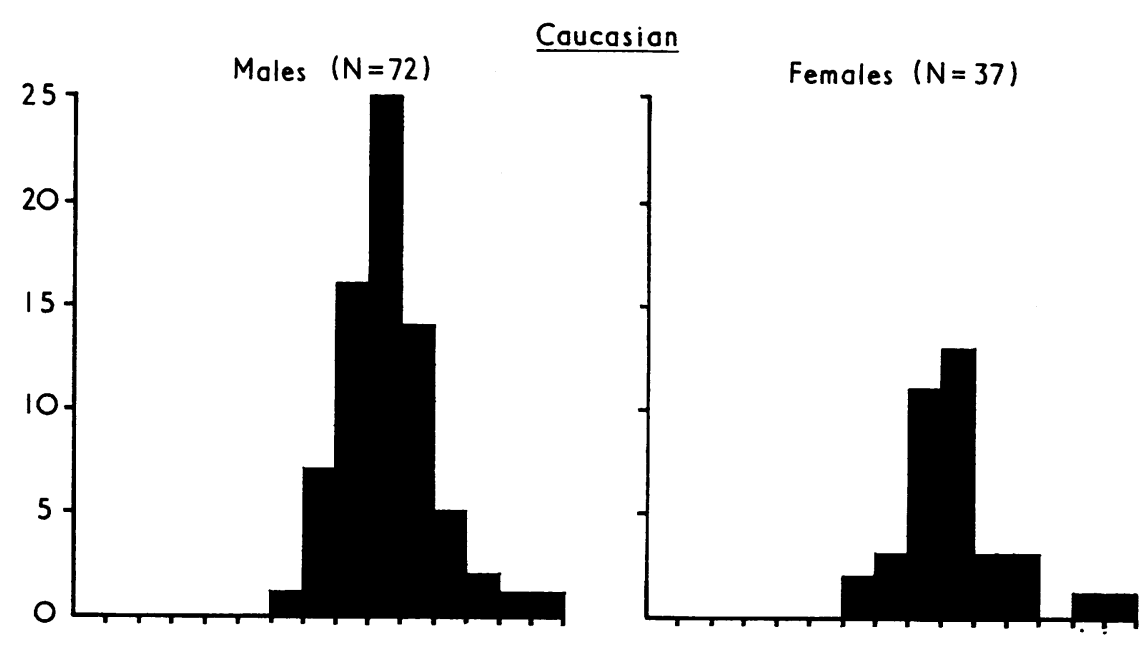

$\frac{n}{0}$
$\frac{7}{2}$
$\frac{2}{0}$
$\frac{5}{0}$
$\frac{0}{2}$

Negroid
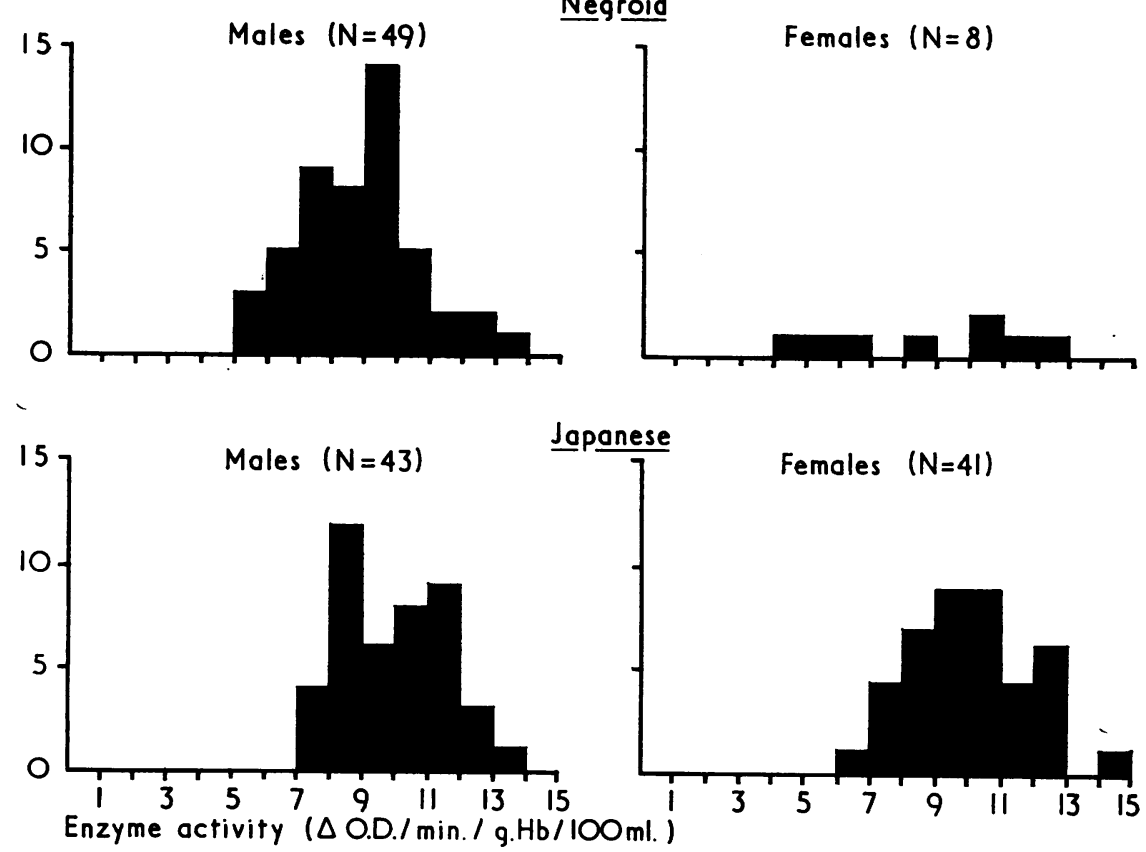

FIG. 1. Distribution of normal G6PD levels among Caucasians, Negroes, and Japanese. 
University of São Paulo. Fig. 3 shows the pedigrees indicating the enzyme rate and electrophoretic type of G6PD found among the family members.

Some relevant characteristics of the families are as follows. Families I and IV are Caucasian of

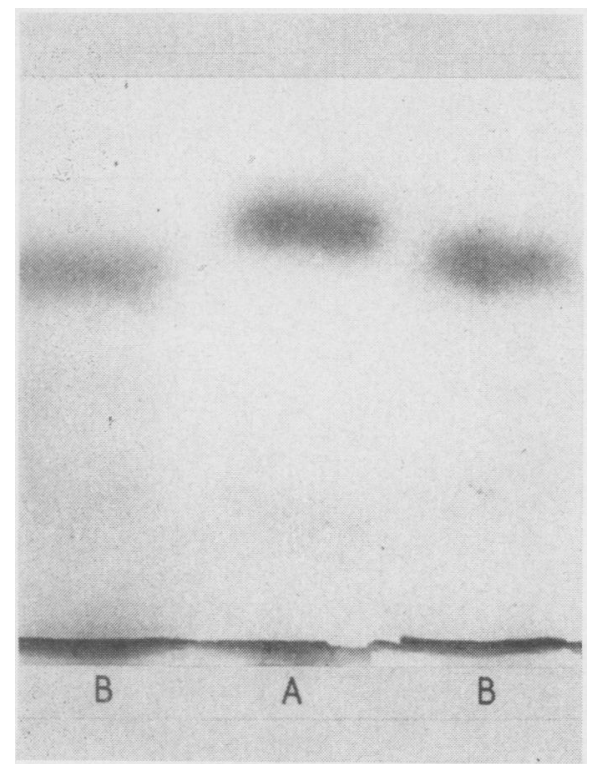

Fig. 2. Electrophoretic bands of a haemolysates identified as A and B types.

TABLE III

FREQUENCY OF G6PD DEFICIENT MALES AMONG DIFFERENT RACIAL GROUPS, INVESTIGATED BY MEANS OF SPECTROPHOTOMETRIC ASSAY

\begin{tabular}{|c|c|c|c|c|}
\hline \multirow[t]{2}{*}{ Race } & \multirow[t]{2}{*}{ Total } & \multicolumn{2}{|c|}{$\begin{array}{l}\text { Deficient } \\
\text { Subjects }\end{array}$} & \multirow{2}{*}{$\begin{array}{l}\text { Heterogeneity } \\
\qquad\left(x^{2}\right)\end{array}$} \\
\hline & & No. & $\therefore$ & \\
\hline $\begin{array}{l}\text { Caucasian } \\
\text { Negro } \\
\text { Japanese }\end{array}$ & $\begin{array}{l}72 \\
49 \\
43\end{array}$ & $\begin{array}{l}1 \\
4 \\
0\end{array}$ & $\left.\begin{array}{l}1 \cdot 4 \\
8 \cdot 2 \\
0\end{array}\right\}$ & $\begin{array}{c}10.3 \\
\text { d.f. }=2 \\
\mathrm{p}<0.01\end{array}$ \\
\hline
\end{tabular}

TABLE IV

DISTRIBUTION OF ELECTROPHORETIC BANDS IDENTIFIED AS A AND B VARIANTS, ACCORDING TO SEX AND RACES OF INDIVIDUALS

\begin{tabular}{l|c|c|c|c|c|c|c|c}
\hline & \multicolumn{6}{|c}{ Electrophoretic Variants in } \\
\cline { 2 - 7 } & \multicolumn{3}{|c}{ Males } & \multicolumn{3}{|c}{ Females } \\
\cline { 2 - 8 } & Total & A & B & Total & A & B & AB \\
\hline Caucasian & 60 & 0 & 60 & 27 & 0 & 25 & 2 \\
Negro & 48 & 5 & 43 & 8 & 0 & 8 & 0 \\
Japanese & 42 & 0 & 42 & 40 & 0 & 40 & 0 \\
\hline Total & 150 & 5 & 145 & 75 & 0 & 73 & 2 \\
\hline
\end{tabular}

Mediterranean ancestry, the propositus being ascertained by presumptive G6PD deficiency. Families II, III, VII, and VIII include mulattoes, the propositus again being ascertained by G6PD deficiency. Similarly, family IX comprises mulattoes, but the propositus was ascertained through haemolytic anaemia: electrophoretic mobility of his enzyme is slightly different from the $A$ and $B$ bands, so that the physico-chemical properties of the enzyme will be investigated. Families $\mathrm{V}$ and VI represent Brazilian whites with no European ancestry, the propositi again being ascertained by presumptive G6PD deficiency. Families $\mathrm{X}$ and XII are also white, but the propositus was ascertained because of thalassaemia. Family XI is Japanese, the propositus being diagnosed as a case of Klinefelter's syndrome. Families XIII, XIV, and XVII include whites studied because of Turners syndrome which had been discovered in the propositi. Family XV were also white, and the propositus had hermaphroditism. Family XVI are mulattoes, and the propositus had testicular feminization syndrome. Family XVIII include a white monozygotic twin pair ascertained for schizophrenia. In addition, one deficient propositus (G6PD activity, 1.45), whose family could not be investigated, is included in Table I.

Genetic analysis of the 18 families supports the fact that erythrocyte G6PD activity is controlled by genes on the $\mathrm{X}$ chromosomes. Fig. 3 shows rates as well as electrophoretic types of the enzyme observed in members of the families. Families I, IV, V, VII, VIII, and IX indicate that deficient males are born to heterozygous mothers. The father of Family V was not available for study but he probably is deficient.

Average G6PD activity of the heterozygous women is about half of that found among normal males and females (Table I), but the values show a wide range, from normal to deficient levels, as seen in Fig. 4. Otherwise, G6PD activity among men is clearly bimodal. These findings are in accordance with Lyon's (1962) hypothesis assuming inactivation of an $\mathrm{X}$ chromosome.

\section{Discussion}

Comparative data on G6PD activity assume not only that the frequency of enzyme-deficient people is different among the racial groups, but that G6PD rates are also variable among the three population groups investigated. It seems worth while to speculate whether those discrepancies are genetic in origin. Since Negroid populations usually have two enzyme variants in relatively high 

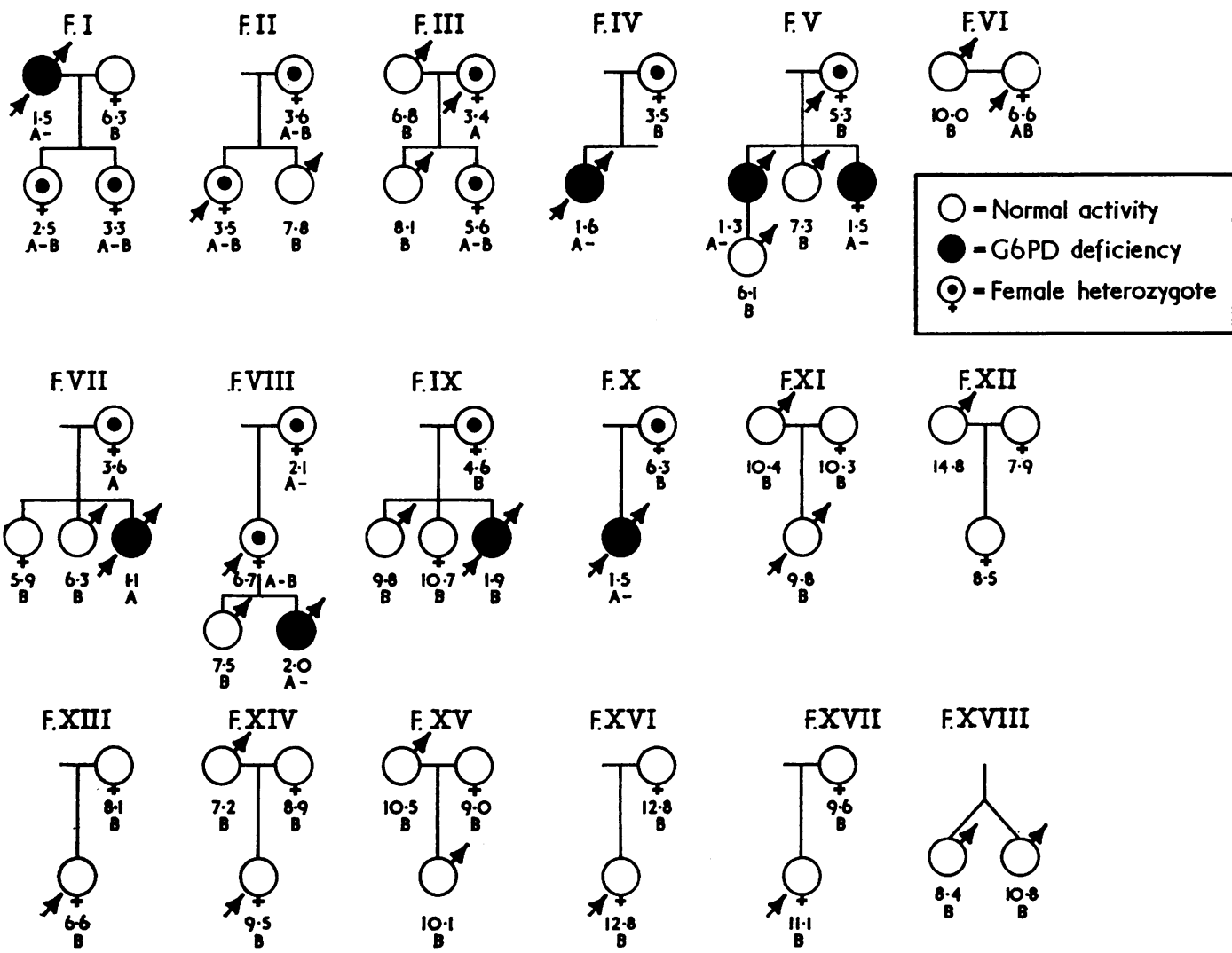

FIG. 3. Pedigrees indicating the enzyme rate and electrophoretic type of G6PD found among the family members.

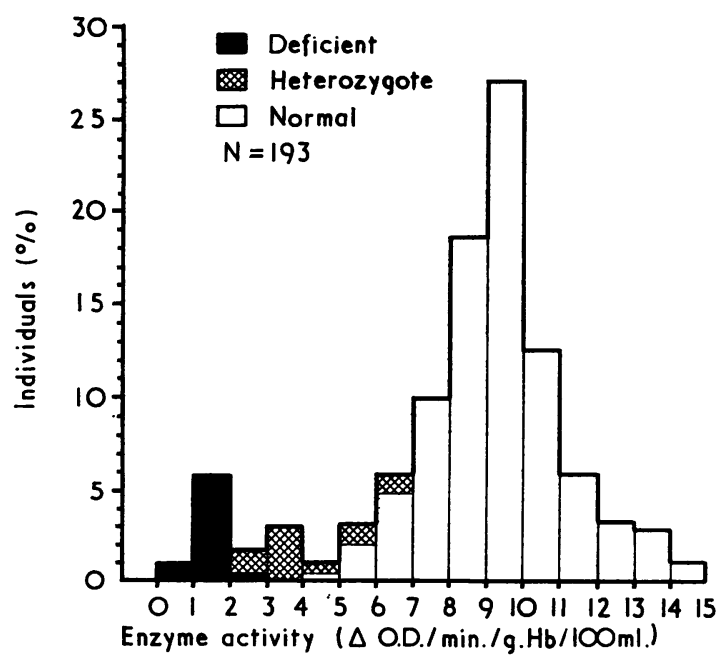

Fig. 4. Distribution of normal, deficient, and heterozygote levels of G6PD activity found among Negro and Caucasian males and females of the population of São Paulo. proportions, it is likely that those isozymes should have a role in determining variable activity levels in the population as a whole. In fact, average normal enzyme activity of Negro subjects belonging to $A$ type (7.31) is lower than that of B subjects (8.98). While the number of A subjects is too small for a definite conclusion, it should explain the relatively low average enzyme activity among Negroes as compared to the values found among Whites and Japanese (Table I).

On this line of reasoning, sib-pair analysis 'indicated a high intrafamilial homogeneity of erythrocyte G6PD activity and considerable interfamily heterogeneity' (Davidson, Childs, and Siniscalco, 1964). While the finding could be interpreted as 'segregation of one allelic gene in a single family and multiple alleles within population', it does not exclude the possibility of homogeneous environmental conditions within families and interfamily heterogeneous environment causing a similar net effect. It seems that the comparison between intra- and inter-family variances of enzyme activity among 
male monozygotic and dizygotic twin (or sib) pairs should shed some light. On the assumption of multiple alleles, the variance ratio is expected to be higher among monozygotic twin males who share both the same $\mathrm{X}$ chromosome and autosomes, while it should not be different among random normal dizygotic twin (or sib) males who should have similar average inter- and intra-family variability in enzyme activity.

The incidence of deficient people among Negroes of São Paulo deserves some comments. Saldanha $(1957,1962 \mathrm{a}, \mathrm{b})$ has reviewed the origin of Brazilian Negroes and estimated that Brazilian Negroes living in the Southern States have about $50 \%$ white genes resulting from racial contacts going back 12 generations. One would expect the incidence of G6PD deficient Negro people to be roughly half that found in African areas where their ancestors came from. Detailed data on the frequency of G6PD deficiency among Sudanese and Bantu groups are not available. There is an indication, however, that the frequency of the A enzyme variant among Negroes in Portuguese Africa should barely exceed $20 \%$ (World Health Organization, 1967), a situation that fits well with the value of $12 \%$ found among Negroes in São Paulo. This figure could appear low when compared with the frequency of $15 \%$ among North-eastern Brazilians (Nance, 1964), a trihybrid population estimated to be $48 \%$ Caucasian, $34 \%$ Negro, and $18 \%$ Indian (Saldanha, 1962a).

Brewer's (Brewer, Tarlov, and Alving, 1962) methaemoglobin reduction test has been applied to a sample of 660 subjects ascertained through the Pre-Natal Clinics in the School of Public Health of the University (P. H. Saldanha et al., 1968, unpublished data). While the sample should be considered as white, it undoubtedly includes many light mulattoes so that data actually represent a mixed population. The incidence of deficient individuals (Table V) is somewhat higher than that found for the white sample discussed here, a situation indicating Negro admixture. The frequency of heterozygous women obtained by means of the methaemoglobin reduction test corresponds to about $37 \%$ of all heterozygotes in the population. Obviously, these females should exhibit enzyme levels near to those found in deficient males. On the basis of gene frequency, the number of deficient women is expected to be too low to make the estimation reliable. However, spectrophotometric assay reveals that the distribution of enzyme rates among heterozygous women presents a wide array, from deficient to normal levels, as anticipated by the $\mathrm{X}$ inactivation theory.
TABLE V

FREQUENCY OF G6PD DEFICIENT SUBJECTS BASED ON THE METHAEMOGLOBIN REDUCTION TEST

\begin{tabular}{l|c|c|c}
\hline \multirow{2}{*}{ Sex } & Total & \multicolumn{2}{|c}{ Deficient Subjects } \\
\cline { 3 - 4 } & & No. & $\%$ \\
\hline Women & 474 & 9 & $1 \cdot 9$ \\
Men & 186 & 5 & $2 \cdot 7$ \\
Total & 660 & 14 & $2 \cdot 1$ \\
\hline
\end{tabular}

Expected heterozygous women $(2 \mathrm{pq} \times$ 100) $=5 \cdot 2 \%$.

Expected deficient homozygous women $\left(q^{2} \times 100\right)=0.07 \%$.

Detected heterozygous women $(1.9 \div$ $5.2 \times 100)=36.5 \%$.

\section{Summary}

The distribution of erythrocyte G6PD activity and electrophoretic variants was investigated among 109 Caucasians, 57 Negroes, and 84 Japanese from the population in São Paulo, Brazil. G6PD activity of haemolysates was studied by means of spectrophotometer assay and electrophoresis in horizontal starch gel. The incidence of deficient subjects was significantly higher among Negroes (8.2\%) compared to that among Whites $(1 \cdot 4 \%)$ and Japanese (nil). The average normal enzyme rates were significantly different among the 3 racial groups but not between the sexes. Mean values among Japanese $(10.00 \pm 0 \cdot 12)$ were higher than those among Whites $(9.51 \pm 0 \cdot 14)$ and Negroes $(8 \cdot 79 \pm 0 \cdot 26)$. Variant $A$ of G6PD was present only in $12 \%$ of Negoes in the population, a situation that fits well with the dihybrid origin of Brazilian Negroes.

Family data were based on 18 propositi and their relatives. Genetic analysis of the families supports that erythrocyte G6PD activity is controlled by genes on the $\mathrm{X}$ chromosomes. The average enzyme activity of the heterozygous females was about half that found among normal males and females. The female rates vary from normal to deficient levels, as expected by assuming inactivation of an $\mathrm{X}$ chromosome. Population dynamics of G6PD mutants are also discussed.

The authors are deeply indebted to Miss Glaucia Colli, Miss Sueli B. Itskan, and Mrs. Sônia G. Saldanha for their technical assistance. The authors have also to thank Mr. Katsuri Wakisaka and Dr. Francisco Antonácio for making subjects available for study.

\section{REFERENCES}

Allison, A. C. (1960). Glucose-6-phosphate dehydrogenase deficiency in red blood cells of east Africans. Nature (Lond.), 186, 531. _, Askonas, B. A., Barnicot, N. A., Blumberg, B. S., and Krimbas, C. (1963). Deficiency of erythrocyte glucose-6-phosphate dehydrogenase in Greek populations. Ann. hum. Genet., 26, 237. 
, and Clyde, D. F. (1961). Malaria in African children with deficient erythrocyte glucose-6-phosphate dehydrogenase. Brit. med. F., 1, 1346.

Beutler, E. (1959). The hemolytic effect of primaquine and related compounds: a review. Blood, 14, 103.

Boyer, S. H., Porter, I. H., and Weibacher, R. G. (1962). Electrophoretic heterogeneity of glucose-6-phosphate dehydrogenase and its relationship to enzyme deficiency in man. Proc. nat. Acad. Sci. (Wash.), 48, 1868.

Brewer, G. J., Tarlov, A. R., and Alving, A. S. (1962). The methemoglobin reduction test for primaquine-sensitivity. A simplified procedure for detecting a specific hypersusceptibility to drug hemolysis. F. Amer. med. Ass., 180, 386.

Childs, B., Zinkham, W., Browne, E. A., Kimbro, E. L., and Torbert, J. V. (1958). A genetic study of a defect in glutathione metabolism of the erythrocyte. Bull. Fohns Hopk. Hosp., 102, 21.

Davidson, R. G., Childs, B., and Siniscalco, M. (1964). Genetic variations in the quantitative control of erythrocyte glucose-6phosphate dehydrogenase activity. Ann. hum. Genet., 28, 61 .

Dern, R. J. (1966). A new hereditary quantitative variant of glucose-6-phosphate dehydrogenase characterized by marked increase in enzyme activity. $\mathcal{f}$. Lab. clin. Med., 68, 560 .

Flatz, G., and Sringam, S. (1964). Glucose-6-phosphate dehydrogenase deficiency in different ethnic groups in Thailand. Ann. hum. Genet., 27, 315.

Gilles, H. M., Fletcher, K. A., Hendrickse, R. G., Lindner, R., Reddy, S., and Allan, N. (1967). Glucose-6-phosphate-dehydrogenase deficiency, sickling, and malaria in African children in South Western Nigeria. Lancet, 1, 138.

Kirkman, H. N., and Hendrickson, E. M. (1963). Sex-linked electrophoretic difference in glucose-6-phosphate dehydrogenase. Amer. F. hum. Genet., 15, 241.

-, McCurdy, P. R., and Naiman, J. L. (1964). Functionally abnormal glucose-6-phosphate dehydrogenase. Cold Spr. Harb. Symp. quant. Biol., 29, 391.

Kruatrachue, M., Bhaibulaya, M., Clougkamnaukoru, K., and Harinasuta, C. (1966). Re-examination of the relationship of erythrocyte glucose-6-phosphate dehydrogenase and malaria in Thailand. World Health Organization Malaria, 66, 533.

- Charoenlarp, P., Chongsuphajaisiddhi, T., and Harinasuta, C. (1962). Erythrocyte glucose-6-phosphate dehydrogenase and malaria in Thailand. Lancet, $2,1183$.

Lee, T., Shih, L., Huang, P., Lin, C., Blackwell, B., Blackwell, R. Q., and Hsia, D. Y. (1963). Glucose-6-phosphate dehydrogenase deficiency in Taiwan. Amer. F. hum. Genet., 15, 126.

Lisker, R., Loria, A., and Cordova, M. S. (1965). Studies on several genetic hematological traits of the Mexican population. VIII. Hemoglobin S, glucose-6-phosphate dehydrogenase deficiency and other characteristics in a malarial region. ibid., 17, 179.

Lyon, M. F. (1962). Sex chromatin and gene action in the mammalian X-chromosome. ibid., 14, 135.

Modiano, G., Benerecetti-Santachiara, A. S., Gonano, F., Zei, G., Capaldo, A., and Cavalli-Sforza, L. L. (1965). An analysis of
ABO, MN, Rh, Hp, Tf and G-6-Pd types in a sample from the (D) human population of the Lecce province. Ann. hum. Genet., 29, 19.

Motulsky, A. G., and Kampbell-Kraut, J. M. (1961). Population genetics of glucose-6-phosphate dehydrogenase deficiency of the $\overrightarrow{\vec{T}}$ red cell. In Proc. Conf. on Genetic Polymorphisms and Geographic Variations in Disease, pp. 159-191. Ed. by B. S. Blumberg. Grune \& Stratton, New York.

$\longrightarrow$, Vandepitte, J., and Fraser, G. R. (1966). Population genetic $\overline{\overline{\mathcal{S}}}$ studies in the Congo. I. Glucose-6-phosphate dehydrogenase deficiency, hemoglobin S, and malaria. Amer. F. hum. Genet., 18, 514.

Nance, W. E. (1964). Genetic tests with a sex-linked marker: ली glucose-6-phosphate dehydrogenase. Cold Spr. Harb. Symp. $\vec{\circ}$ quant. Biol., 29, 415.

Plato, C. C., Rucknagel, D. L., and Gershowitz, H. (1964). Studies on the distribution of glucose-6-phosphate dehydrogenase de- $\vec{\omega}$ ficiency, thalassemia, and other genetic traits in the coastal and mountain villages of Cyprus. Amer. F. hum. Genet., 16, 267.

Porter, I. H., Boyer, S. H., Schulze, J., and McKusick, V. A. (1963). Genetic control of glucose-6-phosphate dehydrogenase. In Proc. के II Intern. Cong. Human Genet., pp. 618-621. Instituto G. -

Mendel, Rome.
Ragab, A. H., El-Alfi, O. S., and Abboud, M. A. (1966). Incidence $\infty \vec{\infty}$ of glucose-6-phosphate dehydrogenase deficiency in Egypt. 윽 Amer. F. hum. Genet., 18, 21.

Saldanha, P. H. (1957). Gene flow from White into Negro populations in Brazil. ibid., 9, 299.

(1962a). Race mixture among Northeastern Brazilian populations. Amer. Anthropologist, 64, 751.

(1962b). Taste sensitivity to phenylthiourea among Brazilian Negroes and its bearing on the problem of White-Negro intermixture in Brazil. Hum. Biol., 34, 179.

Shaker, Y., Onsi, A., and Aziz, R. (1966). The frequency of glucose-6-phosphate dehydrogenase deficiency in the newborns and adults in Kuwait. Amer. F. hum. Genet., 18, 609.

Shows, T. B. Jr., Tashian, R. E., and Brewer, G. J. (1964). Erythrocyte glucose-6-phosphate dehydrogenase in Caucasians: new inherited variant. Science, 145, 1056.

Siniscalco, M., Bernini, L., Filippi, G., Latte, B., Meera Khan, P., 으 Piomelli, S., and Rattazzi, M. (1966). Population genetics of $Q$ haemoglobin variants, thalassaemia and glucose-6-phosphate dehydrogenase deficiency, with particular reference to the malaria hypothesis. Bull. Wld Hlth Org., 34, 379.

- Latte, B., and Motulsky, A. G. (1961). Favism and thalassaemia in Sardınia and their relationship to malaria. Nature (Lond.), 190, 1179.

Smithies, O. (1959). Zone electrophoresis in starch gels and its application to studies of serum proteins. Advanc. Protein Chem., 14, 65 .

World Health Organization (1967). Standardization of procedures for the study of glucose-6-phosphate dehydrogenase. Report of a WHO Scientific group. Wld Hlth Org. techn. Rep. Ser., No. 366. 